\title{
AN ANALYSIS OF THE WRITTEN GRAMMATICAL ERRORS BY USING DESCRIPTIVE TEXT IN THE SIXTH SEMESTER STUDENTS' AT PASIFIK UNIVERSITY OF MOROTAI
}

\author{
Noviyanti Hakim \\ noviyanti.hakim29@gmail.com
}

\section{Pasifik University of Morotai, Maluku Utara}

\begin{abstract}
Error Analysis is one of the major topics in the field of second language acquisition research. Error is a deviation from the adult grammar of a native speaker. Errors made by the learners may give contribution in understanding the process of second language acquisition. An error analysis has some contributions to the teaching and learning process. Writing is the most difficult one for all language users whether the language is the first, second, or foreign language, because writing is an extremely complex cognitive activity. In this study focus on the descriptive qualitative that analyze and to classify the types of students' grammatical errors in essays descriptive paragraph. The objective are (1) What errors were identified in the students' essays?, (2) What grammatical rules were applied to justify the corrections made?, (3) How frequent were the errors commited in the essays?. The researcher took 23 students as the samplesize. The results showed that using error analysis can be improved students' in understanding the basic grammar rules. Improvement basic grammar rules such as subject and verb agreement, word usage, sentence fragment, verb tense, spelling, punctuation, pronouns, use of article and linking verbs, adjective. The knowledge about grammar or structure factors also have big rule in writing because a sentence will be meaningful if it is arranged in right patterns. Moreover, the students should know and understand about the basic grammar rules.
\end{abstract}

Keywords: error analysis, descriptive, grammatical errors.

\section{INTRODUCTION}

Being able to communicate effectively is the most important of all life skills. The ability to communicate information accurately. Clearly and as intended, is a vital life skill and something that should not be overlooked. However, writing and speaking following correct grammar are not as easy as expected. The purpose of good grammar is to ensure that what you write is correctly comprehended and is easy and enjoyable to read. Writing involve a language production; therefore, they are referred as productive skills. Listening and readinginvolve receiving messages, therefore, they are referred as receptive skills.

Richards, J. C and Renanda, W.A. (2002) states that writing is the most difficult skill for second language learners 


\section{ESTEEM: JOURNAL OF ENGLISH STUDY PROGRAMME P-ISSN 2622-9323 \\ E-ISSN 2622-2213}

to master. The skills involved in writing are highly complex, thought that writing is far from a simple matter of transcribing language intowritten symbols.

Jaya (2017) In learning English as a foreign language, writing is categorized as one of the hardest and difficult skills because it requires grammatical accuracy, punctuation, capitalization, spelling, and vocabulary. It is a means of expressing thoughts, ideas, and feelings. From the explanation above, it is clear that students are expected to be able to write in any form, especially descriptive paragraph. The problem is that writing is the most difficult skill to be learned. Writing is complicated because the writer needs to do everything at once. The writer must produce words, sentences, paragraphs, and extended compositions all at the same time. In this study, using the basic grammar rules such as on punctuation, capitalization, spelling, subject and verb agreement, sentence fragment, verb usage, run-on sentence and use of article, the error analysis was conducted along with the giving of corrections/justifications why these errors were identified.

\section{REVIEW OF LITERATURE}

Error analysis is the study of errors made by the second and foreign language learners. Error analysis may be carried out in order to find out how well someone knows a language, find out how a person learns a language and obtain information on common difficulties in language learning, as an aid in teaching or in the preparation of teaching.

Candling R. B (2001) considers error analysis as ,the monitoring and analysis of learner"s language"e. Writing "as a way of sharing personal meanings and writing courses emphasize the power of the individual to construct his or her own views on a topic" (Ken Hyland, 2003). Errors are part of the learner inter language that is the version of the language which a learner has at any one stage of development and which is continually reshaped as he or she aims toward full mastery (Jeremy Harmer , 2001).

Error analysis as the study and analysis of the errors made by second language learners that errors are the flawed side or learner speech or writing. they are those parts of conversation or composition that deviate from same selected norm of mature language performance (Richards, J. C., Schmidt, R. 2002). Correcting error is done if there is some understanding of why the error occurred, thus error analysis is the study of errors to see what processes gave rise to them. error is a systematic deviation, when a learner has not learnt something and consistently get it wrong (Nation and Newton, 2001).

\subsection{The Procedure of Error Analysis}

There are some procedures of error analysis which come from some linguistic experts Ellis, Rod. (1997) concluded that the procedures of error analysis such as 


\section{ESTEEM: JOURNAL OF ENGLISH STUDY PROGRAMME P-ISSN 2622-9323 \\ E-ISSN 2622-2213}

identifying errors, describing errors, explaining errors, evaluating errors. Where four procedures that was very important and needed in the error analysis. Without of one of the procedure, the analysis will be doing less truth. These procedure relate to each other, which in the error analysis, usually step that should be done by the writer after identifying error is the writer should be done describe the overall error and should detail, this purposes that the writer know clearly the frequency errors that the students made in using adjective in descriptive text writing, and also know the development of students in target language. After describing the error, the next step is the writer should explaining and evaluating error, that ${ }^{\text {ee }} \mathrm{s}$ all meant that the writer know the types of errors the students make and the source of the reason why the students make error in descriptive text writing. and the final step is evaluating error, this purposes that writer can specify what should be emphasized or repaired to test result of the students in using descriptive text writng.

\subsection{Types of Errors}

There are several types of error. It consists of four item which is discussed further in this sub-chapter. They are parts of speech, sentence patern, subject verb agreement and tense. These type of error were mostly made by the students.

\subsection{Parts of speech}

The sentence maybe further divided according to the function is classified as a different part of speech. The words that

form the central core of the sentence around which all the other words "cluster" are the part of speech known as nouns (or pronoun) and verbs; the word that modify the central core words are the part of speech called adjectives and adverb; the word that show a particular kind of connecting relationship between these four parts of speech are called prepositions and conjunction. Pronouns may occur before a verb, after a verb, after a preposition, or before a noun. Subject Verb Agreement. A verb must agree with its subject in number (singular or plural) and in person (first, second, third). When subject and verb are correctly matched. It can be said that they are grammatically agree. Meanwhile, "causes of error are mother tongue interference, overgeneralization, and error encouraged by teaching material and method" (Olasehinde, 2001). However, Brown (2002) adds communication strategies as the fourth sources of error. As mentioned previously, there are four sources of error in learning language.

\section{a. Inter lingual error}

Inter lingual error means errors attributed to the native language (L1). There are inter lingual errors when the learners first get language habits (pattern, system, or rules) which interfere or prevent the learners from acquiring the pattern and rules of the second language manifest some degree of different form and some degree of similarity with the equivalent item in learning the first language. 


\section{ESTEEM: JOURNAL OF ENGLISH STUDY PROGRAMME \\ P-ISSN 2622-9323 \\ E-ISSN 2622-2213}

\section{b. Intra lingual error}

Intra lingual errors are errors due to the misunderstanding of the language being learned (L2), independent of the native language

\section{c. Context of learning}

Context refers to the classroom situation that is built by both teacher and material. This situation can urge the learners to make faulty hypotheses about the language.

\section{d. Communication strategies}

Learners obviously use production strategy in order to enhance getting their message across. But at the same time these techniques can themselves become a source of error".

\section{RESEARCH METHODOLGY}

This research made use of the descriptive qualitative and quantitative methods to analyze the students ${ }^{\text {ee }}$ error in the essays written in descriptive paragraph form. Qualitative type of research describes, reports and creates key concepts, theory and ideas. (Arikunto, 2006) defines descriptive research has not purpose to test the certain hypothesis, but just describe some variable and condition naturally.

The procedures of error analysis was utilized by the researcher. Quantitavely, this study counted the number of errors and classified them according to the frequency of errors. In collecting the necessary data, the researcher evaluated the students ${ }^{\text {ee }}$ essays. Louis (2007) thought that observation enables the researcher to gather data on: the physical setting, human setting, interactional setting, and program setting. The researcher interpreted the data using the basic grammar rules such as punctuation, capitalization, spelling, sentence fragment, verb tense, subject verb agreement, redudant of descriptors, article, linking verbs, pronoun, adjectives, punctuation as the justification of the error/s committed.

The research analyzed the essays submitted by the sixth semester students at pasifik university of morotai. This study used statistical tools percentage to count the data. The percentage was used to determine the proportion of errors to the total number of errors and apply the ranking system in order to determine which are predominant and are less committed.

The formula is:

$$
\mathrm{P}=\frac{F}{N} \times 100 \%
$$

Where:

$$
\begin{aligned}
& \mathrm{P}=\text { precentage } \\
& \mathrm{F}=\text { Frequency } \\
& \mathrm{N}=\text { total number of errors }
\end{aligned}
$$

\section{THE FINDINGS AND DISSCUSION}

In this section, presents discussion of the result and findings of the study. The result of investigation is presented in tabular forms with the corresponding interpretations, identification and corrections to answer the problems being sought for in this study. 


\section{ESTEEM: JOURNAL OF ENGLISH STUDY PROGRAMME \\ P-ISSN 2622-9323 \\ E-ISSN 2622-2213}

Table 1: Result of error analysis students' essays

\begin{tabular}{ccc}
\hline Types of errors & Frequency of Error & Precentage \\
& & \\
Capitalization & 8 & $7.21 \%$ \\
Misplaced descriptors & 1 & $0.90 \%$ \\
Sentence Fragment/ & 16 & $14.41 \%$ \\
Incom pelete sentence & & \\
Verb Tense & 2 & $1.80 \%$ \\
Subject Verb Agreement & 18 & $16.22 \%$ \\
Redudant of descriptors & 8 & $7.21 \%$ \\
Word usage & 7 & $6.31 \%$ \\
Article & 6 & $5.41 \%$ \\
Use of Linking verb & 5 & $4.50 \%$ \\
Run on Sentences & 11 & $9.91 \%$ \\
Pronoun & 5 & $4.50 \%$ \\
Spelling & 16 & $14.41 \%$ \\
Adjectives & 3 & $2.70 \%$ \\
Punctuation & 5 & $4.50 \%$ \\
SUM & & \\
\hline
\end{tabular}

The distribution of errors were as follows: subject and verb agreement, $16.22 \%$, spelling, $\quad 14.41 \%$; sentence fragment, $14.41 \%$, run-on sentences, $9.91 \%$, capitalization, $7.21 \%$, redundant use of descriptors, with $7.21 \%$, article, 5.41\%, word usage, $4.5 \%$, pronoun usage, $4.5 \%$, punctuation, $4.5 \%$, adjectives, $2.7 \%$, errors on verb tense $1.8 \%$, and misplaced descriptors, $0.9 \%$. These findings more or less agree with the findings of a research entitled "Common Grammatical Errors in the English Essay Writing by $3^{\text {rd }}$ Secondary Students in leading schools of Eastern UAE" that the most common grammatical errors found in studentse essays were on capitalization, verb tense, subject and verb agreement, word order, prepositions, articles and plurality. Based from the analysis, many students made errors in subject and verb agreement.

Capitalization, students cannot decide whether an expression or word should be capitalized or not. Students use capital letter or not in a certain word or, it is simply said, it is out of the rule. Students also use the wrong capital letter in particular words. They did not put any capital letter at the beggining of the sentence, in the name of a person, place, and abbreviation. In this case the students did not use capitalization. Misplaced desriptors. Similar to the previous findings, the error was on not being able to write sentences completely. Because of the flourishing ideas of the writer, sentence organization was affected. 


\section{ESTEEM: JOURNAL OF ENGLISH STUDY PROGRAMME P-ISSN 2622-9323 \\ E-ISSN 2622-2213}

\begin{tabular}{|c|c|c|c|}
\hline Errors & Types of Error & Justification & Correction \\
\hline $\begin{array}{l}\text { the gold leaf } \\
\text { presents the } \\
\text { flame of } \\
\text { Freedom. }\end{array}$ & $\begin{array}{l}\text { Capitalization } \\
\text { error }\end{array}$ & $\begin{array}{l}\text { Capitalization means writing a word with } \\
\text { first letter as a capital letter. } \\
\text { "A sentence should begin with a capital } \\
\text { letter." }\end{array}$ & $\begin{array}{l}\text { The gold leaf } \\
\text { represents the flame } \\
\text { of Freedom. }\end{array}$ \\
\hline $\begin{array}{l}\text { Amanda } \\
\text { Manopo is } \\
\text { beautiful and } \\
\text { smart girl }\end{array}$ & $\begin{array}{c}\text { Use of } \\
\text { Descriptors }\end{array}$ & $\begin{array}{l}\text { The word "girl" need not be used because } \\
\text { Amanda Manopo refers to the girl already. }\end{array}$ & $\begin{array}{l}\text { Amanda Manopo is } \\
\text { beautiful and smart. }\end{array}$ \\
\hline $\begin{array}{l}\text { The schoolbuilt } \\
\text { January } 21^{\text {st }} \\
\text { 1968. }\end{array}$ & $\begin{array}{l}\text { Sentence } \\
\text { Fragment/Incomp } \\
\text { lete Sentence. }\end{array}$ & $\begin{array}{l}\text { In this sentence used verb ,to be } \mathrm{e}^{\mathrm{ee}} \text { in the past } \\
\text { such as „was }\end{array}$ & $\begin{array}{l}\text { The school was } \\
\text { built in January 21, } \\
1968 .\end{array}$ \\
\hline $\begin{array}{l}\text { We spend } \\
\text { almost the } \\
\text { whole day } \\
\text { boating. }\end{array}$ & Verb Tense & $\begin{array}{l}\text { Use of tense, past tense of ,spend }{ }^{e e} \text { is } \\
\text { „spent }{ }^{e e} \text {. }\end{array}$ & $\begin{array}{l}\text { We spent boating } \\
\text { the whole day. }\end{array}$ \\
\hline $\begin{array}{l}\text { The rabbit have } \\
\text { a two long ear. }\end{array}$ & $\begin{array}{l}\text { Subject and Verb } \\
\text { Agreement }\end{array}$ & $\begin{array}{l}\text { "Fell" is the past tense of "fall" } \\
\text { Have is the root VER B and is generally used } \\
\text { alongside the PRONOUNS I / You / We / } \\
\text { Ye and They and PLURAL NOUNS. } \\
\text { Generally, have is a PRESENT TENSE } \\
\text { word. Has is used alongside the } \\
\text { PRONOUNS He / She / It and Who and } \\
\text { SINGULAR NOUNS. }\end{array}$ & $\begin{array}{l}\text { A rabbit has two, } \\
\text { long ears. }\end{array}$ \\
\hline $\begin{array}{l}\text { Sultan Aji } \\
\text { Sulaiman } \\
\text { Airport is one of } \\
\text { the best airport } \\
\text { in the world. }\end{array}$ & use of adjective & $\begin{array}{l}\text { "One of the" should be followed by a word } \\
\text { that is plural in form. } \\
\text { The adjectival clause "one of the "should be } \\
\text { followed by a plural subject" }\end{array}$ & $\begin{array}{l}\text { Sultan Aji Sulaiman } \\
\text { is one of the best } \\
\text { airports in the } \\
\text { world. }\end{array}$ \\
\hline
\end{tabular}

A sentence fragment is a group of words that is only part of a sentence and does not express a complete thought. Usually sentence fragments are pieces of sentences that have become disconnected from the main clauses. Some fragments are incomplete because they lack either a subject or a verb. Verb tense is a form taken by a verb to indicate the time at which the action has occurred or is occuring. Some of students made mistake in using the correct verb tense.

They were confused in using tenses as to whether the event has happened already or will happen in the future. Verb tense is the verb used to indicate the time at which the action or statement occurs.
Subjects and verbs must agree with one another in number (singular or plural). Thus, if a subject (the person or thing doing the action) is singular, its verb (the word representing the action) must also be singular; if a subject is plural, its verb must also be plural. Students also made errors in the redundant use descriptors because of not knowing when words are already used excessive and unnecessary because of lack of vocabulary.

Redundancy usually involves repeating something or adding information that is completely unnecessary. An adjective is a part of speech which describes, identifies, or quantifies a noun or pronoun. So basically, the main function of 


\section{ESTEEM: JOURNAL OF ENGLISH STUDY PROGRAMME \\ P-ISSN 2622-9323 \\ E-ISSN 2622-2213}

an adjective is to modify a noun or a pronoun so that it will become more spesific and interesting, instead of just one word, a group of words with a subject and a verb, can also function as an adjective.

\begin{tabular}{|c|c|c|c|}
\hline Errors & Type/s of Error & Justification & Correction \\
\hline $\begin{array}{l}\text { It has a very long } \\
\text { neck and long lags. }\end{array}$ & Redund ancy & $\begin{array}{l}\text { The adjective "long" was used } \\
\text { redundantly. "lags" should be } \\
\text { replaced by "legs". }\end{array}$ & $\begin{array}{l}\text { The girrafe has long } \\
\text { neck and legs. }\end{array}$ \\
\hline $\begin{array}{l}\text { The feather coloures } \\
\text { white. }\end{array}$ & Word Usage & $\begin{array}{l}\text { "Feathers are absent in rabbits. } \\
\text { These animals have "fur" instead. }\end{array}$ & $\begin{array}{l}\text { The feather is white in } \\
\text { color. The rabbite's fur } \\
\text { is white. }\end{array}$ \\
\hline $\begin{array}{l}\text { Giraffe is an tall } \\
\text { animal. }\end{array}$ & Article & $\begin{array}{l}\text { A is used with singular countable } \\
\text { nouns that begin with a consonant. } \\
\text { An is used with singular countable } \\
\text { nouns that begin with a vowel. }\end{array}$ & $\begin{array}{l}\text { Giraffe is a tall } \\
\text { animal. }\end{array}$ \\
\hline $\begin{array}{l}\text { She is have some } \\
\text { account in social } \\
\text { media. }\end{array}$ & $\begin{array}{l}\text { Use of Linking } \\
\text { Verb }\end{array}$ & $\begin{array}{l}\text { "Is have" should be replaced by } \\
\text { „has "e for third singular person } \\
\text { „she" }\end{array}$ & $\begin{array}{l}\text { She has an account in } \\
\text { social media }\end{array}$ \\
\hline $\begin{array}{l}\text { She has long hair and } \\
\text { straight hair and } \\
\text { black colour. }\end{array}$ & Run-on sentence & $\begin{array}{l}\text { The students translated the } \\
\text { Indonesian language into English } \\
\text { directly and did not know the } \\
\text { difference between singular and } \\
\text { plural form. }\end{array}$ & $\begin{array}{l}\text { She has a long, } \\
\text { straight and black hair. }\end{array}$ \\
\hline $\begin{array}{l}\text { I have some idol } \\
\text { from many singers } \\
\text { on Indonesia. }\end{array}$ & $\begin{array}{l}\text { Pronoun } \\
\text { Agreement }\end{array}$ & $\begin{array}{l}\text { "The word some is used as a } \\
\text { determiner. It is used to modify } \\
\text { nouns. Some can be used with both } \\
\text { countable and uncountable nouns, } \\
\text { show an indefinite quantity or } \\
\text { number." }\end{array}$ & $\begin{array}{l}\text { I have an idol singer } \\
\text { from among the } \\
\text { singers in Indonesia. }\end{array}$ \\
\hline $\begin{array}{l}\text { The National } \\
\text { munument is located } \\
\text { at the centre of } \\
\text { Merdeka Square. }\end{array}$ & Spelling & $\begin{array}{l}\text { The word "monument" was } \\
\text { mis spelled. } \\
\text { should be replaced by } \\
\text { "Monument". } \\
\text { "Everyone should use a dictionary } \\
\text { or turn on Spell Check. }\end{array}$ & $\begin{array}{l}\text { The National } \\
\text { Monument is located } \\
\text { at the Centre of } \\
\text { Merdeka Square. }\end{array}$ \\
\hline $\begin{array}{l}\text { Every class has } \\
\text { doors, windows and } \\
\text { stairs. }\end{array}$ & Punctuation & $\begin{array}{l}\text { "Use commas to separate three or } \\
\text { more words, phrases, or clauses in } \\
\text { a series." } \\
\text { "Use commas to separate } \\
\text { adjectives of equal rank." }\end{array}$ & $\begin{array}{l}\text { Every classroom has } \\
\text { doors. windows, and } \\
\text { stairs. }\end{array}$ \\
\hline
\end{tabular}

Word usage is often used refer to the usage of the elements in the clause, elements, which are often realized by phrases or clauses rather than just one word such as subject, verb, object, predicate, and adverb. Indonesian word form is different from English word form. Some students made errors in using the word form in their composition. For instance, students misuse a word thus casting a different meaning and thought. An article is a word that is used with a noun to indicate the type of reference being made by the noun. English has two articles: the and a/an. The is used to refer to specific or particular nouns; a/an is used to modify non-specific or non-particular nouns. We call the the definite article and a/an the indefinite article. A linking verb is a verb connects a subjects to its predicate without expressing an action. A linking verb is used to re-identfy or describe its subject.

Run on sentence has at least two parts, either one of which can stand by itself (in other words, two independent clauses), 


\section{ESTEEM: JOURNAL OF ENGLISH STUDY PROGRAMME P-ISSN 2622-9323 \\ E-ISSN 2622-2213}

but the two parts have been smooshed together instead of being properly connected. Pronoun is defined as a word or phrase that may be substituted for a noun or noun phrase, which once replaced, is known as the pronoun ${ }^{\text {ee }}$ antecedent. Spelling is the process of writing a word correctly. The difficulty in writing word or words correctly can be attributed to the lack of knowledge, poor reading habits and lack of exposure. A good number of students misspelled even simple words. Punctuation is the practice of inserting various marks in written texta in order to aid interpretation. It is used to indicate the relationship between words, phrases, and clauses. Period [.], comma [,], question mark [?], exclamation point [!], colon [:], semicolon [;], etc, are the kinds of punctuation marks.

\section{CONCLUSION}

The result of this study shows that the errors in the essays submitted by the students were mostly grammatical in nature, vocabulary shortage and inconsistency of ideas. The basic grammar rules that was used as reference to justify the errors made was simple but complete, easy to use and easy to understand. The current findings of this study have gone some way towards enhancing the understanding of categorizing and analyze the errors in English essays writing of the sixth semester students. The grammatical rules applied to justify the corrections made are the basic grammar rules that include capitalization, word usage, spelling, punctuation, sentence fragment, verb usage, use of article, verb tense, use of adjectives, subject and verb agreement, use of descriptors, linking verbs, pronouns, The distribution of the frequency of errors were as follows: subject and verb agreement, $16.22 \%, \quad$ spelling, $14.41 \%$; sentence fragment, $14.41 \%$, run-on sentences, 9.91\%, capitalization, $7.21 \%$, redundant use of descriptors, with $7.21 \%$, article, $5.41 \%$, word usage, $4.5 \%$, pronoun usage, $4.5 \%$, punctuation, $4.5 \%$, adjectives, $2.7 \%$, errors on verb tense $1.8 \%$, and misplaced descriptors, $0.9 \%$ and the grammar exercises proposed by the researcher are practical and suitable to sixth semester students mental abilities and interest. 


\section{ESTEEM: JOURNAL OF ENGLISH STUDY PROGRAMME \\ P-ISSN 2622-9323 \\ E-ISSN 2622-2213}

\section{REFERENCES}

Arikunto S. Co.13 "Prosedur Penelitian Suatu Pendekatan Praktik". (Jakarta: Rineka Cipta, 2006), 30 .

Candling, R.B. 2001. Vocabulary and Language Teaching. New York: Longman Inc.

Ellis, Rod. 1997. Second Language Acquisition. Oxford: Oxford University Press. p. 20.

H. Douglas Brown. Principle of Language and Teaching. Fourth Edition. (Addison Wesley Longman. Inc. 2000). P. 217.

Jaya, A. 2017. Sentence Patterns of Narrative Text in English Textbook in Indonesia.

English Community Journal. 1 (2)

Jeremy Harmer. The Practice of English Teaching. (Person Education Limited. 2001) p.8.

Ken Hyland, Second Language Writing, (Cambridge: Cambridge University Press, 2003), p.9.

Louis Cohen. Research Methods in Education. Sixth ed. (USA and Canada: Routledge. 2007).

Nation, I. S. P., and Newton J. (2001). Teaching EFL listening and speaking. New York: Routledge/Taylor and Francis Group. p. 140-141.

Norrish, J. 1987. Language Learning and Their Error. London: Macmillan Publisher Ltd. p. 35 .

Richards, J. C., and Schmidt, R. (2002). Dictionary of Language Teaching \& Applied Linguistics. Pearson Education Limited. London: Longman. p. 184.

Olasehinde, M.O. 2002. Error analysis and remedial pedagogy. In Babatunde S. T. and D.S. Adeyanju (eds.). Language, Meaning and Society. Ilorin : Itaytee Press and Publishing Co. 